\title{
Effects of dopamine on leptin release and leptin gene $(O B)$ expression in adipocytes from obese and hypertensive patients
}

This article was published in the following Dove Press journal: International Journal of Nephrology and Renovascular Disease 26 November 2013

Number of times this article has been viewed

\author{
Cleto Alvarez-Aguilar ${ }^{1-3}$ \\ Alfonso Rafael Alvarez- \\ Paredes ${ }^{2}$ \\ Bengt Lindholm ${ }^{4}$ \\ Peter Stenvinkel ${ }^{4}$ \\ Elvia García-López ${ }^{4}$ \\ Oliva Mejía-Rodríguez ${ }^{5}$ \\ Joel Edmundo López-Meza ${ }^{6}$ \\ Dante Amato ${ }^{7}$ \\ Ramon Paniagua ${ }^{8}$ \\ 'Hospital General Regional NI, \\ Instituto Mexicano del Seguro Social \\ (IMSS), Morelia, ${ }^{2}$ Facultad de Ciencias \\ Médicas y Biológicas "Dr. Ignacio \\ Chávez" Universidad Michoacana de \\ San Nicolás de Hidalgo (UMSNH), \\ Morelia, Michoacán, ${ }^{3}$ División de \\ Estudios Superiores, Universidad \\ Nacional Autónoma de México \\ (UNAM), México DF, México; \\ ${ }^{4}$ Department of Clinical Science \\ Intervention and Technology, \\ Karolinska Institutet, Stockholm, \\ Sweden; ${ }^{5}$ Coordinación Delegacional \\ de Investigación en Salud, IMSS, \\ Morelia, ${ }^{6}$ Centro Multidisciplinario de \\ Estudios en Biotecnología (CMEB), \\ UMSNH, Morelia, Michoacán, ${ }^{7}$ Facultad \\ de Estudios Superiores Iztacala, \\ UNAM, Tlalnepantla, ${ }^{8}$ Unidad de \\ Investigación en Enfermedades \\ Nefrológicas, Hospital de \\ Especialidades, CMN Siglo XXI, \\ IMSS, México DF, México
}

Correspondence: Cleto Alvarez-Aguilar Hospital General Regional $N^{\circ}$, Instituto Mexicano del Seguro Social Avenida Madero Poniente I200, Morelia, Michoacán 58000, México

$\mathrm{Tel}+52443324 \quad 1610$

Fax +52 $443324 \quad 1610$

Email calvareza@yahoo.com.mx
Background: A reduction of dopaminergic (DAergic) activity with increased prolactin levels has been found in obese and hypertensive patients, suggesting its involvement as a pathophysiological mechanism promoting hypertension. Similarly, leptin action increasing sympathetic activity has been proposed to be involved in mechanisms of hypertension. The aim of this study was to analyze the effects of DA, norepinephrine (NE), and prolactin on leptin release and leptin gene $(O B)$ expression in adipocytes from obese and hypertensive patients.

Methods: Leptin release and $O B$ gene expression were analyzed in cultured adipocytes from 16 obese and hypertensive patients treated with DA $(0.001,0.01,0.1$, and $1.0 \mu \mathrm{mol} / \mathrm{L})$, $\mathrm{NE}(1.0 \mu \mathrm{mol} / \mathrm{L})$, insulin $(0.1 \mu \mathrm{mol} / \mathrm{L})$, and prolactin $(1.0 \mu \mathrm{mol} / \mathrm{L})$, and from five nonobese and normotensive controls treated with DA $(1 \mu \mathrm{mol} / \mathrm{L}), \mathrm{NE}(1 \mu \mathrm{mol} / \mathrm{L})$, insulin $(0.1 \mu \mathrm{mol} / \mathrm{L})$, and prolactin $(1.0 \mu \mathrm{mol} / \mathrm{L})$.

Results: A dose-related reduction of leptin release and $O B$ gene messenger ribonucleic acid expression under different doses of DA was observed in adipocytes from obese hypertensive patients. Whereas prolactin treatment elicited a significant increase of both leptin release and $O B$ gene expression, NE reduced these parameters. Although similar effects of DA and NE were observed in adipocytes from controls, baseline values in controls were reduced to $20 \%$ of the value in adipocytes from obese hypertensive patients.

Conclusion: These results suggest that DAergic deficiency contributes to metabolic disorders linked to hyperleptinemia in obese and hypertensive patients.

Keywords: dopamine, leptin, cultured adipocytes, obesity, hypertension

\section{Introduction}

The association between hypertension, obesity, and insulin resistance ${ }^{1}$ is closely linked to increased sympathetic activity. ${ }^{2}$ The dopaminergic (DAergic) influence on blood pressure regulation, including DAergic-mediated inhibition of norepinephrine (NE) at sympathetic neuroeffector endings, leads to a reduction of central and peripheral DAergic activity and a hypertensive condition, possibly accounting for essential hypertension. ${ }^{3}$ Clinical studies show a DAergic modulation of sympathetic activity in hypertensive and obese individuals, ${ }^{4}$ and DAergic agonists have been successfully used as a treatment for hypertension by reducing adrenergic neurotransmission at sympathetic endings. ${ }^{5}$ As bromocriptine treatment in obese humans elicited a reduction of serum leptin values ${ }^{6}$ and improved insulin sensitivity, ${ }^{7}$ this indirectly suggests beneficial effects of reduced DAergic activity.

Leptin, the peptide product of the obesity gene $(O B)$ expressed and released mainly from adipocytes, ${ }^{8}$ plays an important role in the regulation of food intake, energy 
expenditure, and body weight regulation. ${ }^{9}$ High plasma levels of leptin in obese subjects reflect leptin resistance, ${ }^{10}$ which may contribute to obesity-related hypertension, ${ }^{11}$ ie, chronic leptin infusion increases sympathetic activity and arterial pressure. ${ }^{12}$ Whereas several endogenous compounds, including insulin, ${ }^{13}$ glucocorticoids, ${ }^{14}$ and prolactin, ${ }^{15}$ may increase $O B$ gene expression from adipocytes, NE induces the opposite effect. ${ }^{16}$ Hence, a leptin-mediated pathophysiological influence of these endogenous compounds has been suggested in obesity and hypertension. ${ }^{17}$

The aim of this study was to explore if DAergic deficiency could contribute at least in part to metabolic disorders, particularly hyperleptinemia in obese and hypertensive patients. For this purpose, we examined the effects of DA, $\mathrm{NE}$, insulin, and prolactin on leptin release and $O B$ gene expression in adipocytes from obese hypertensive patients and age- and sex-matched nonobese normotensive patients undergoing elective surgery.

\section{Materials and methods Study design}

The study comprised 16 obese hypertensive patients (ten women and six men, body mass index [BMI] $\geq 30 \mathrm{~kg} / \mathrm{m}^{2}$ ) and five nonobese normotensive patients (three women and two men, BMI $<30 \mathrm{~kg} / \mathrm{m}^{2}$ ) serving as controls who underwent elective surgery for cholecystitis $(n=7)$, umbilical hernia $(n=12)$, lipoma $(n=1)$, and polycystic ovary $(n=1)$. The hypertensive patients had on at least two occasions during a 1 -week interval systolic blood pressure $\geq 140 \mathrm{mmHg}$ and/or diastolic blood pressure $\geq 90 \mathrm{mmHg}$, and mean blood pressure $\geq 107 \mathrm{mmHg}$ (after a 5-minute rest period and seated). No subjects had renal, hepatic, or cardiac disease. Six subjects were taking antihypertensive drugs: angiotensin-converting enzyme (ACE) inhibitors $(n=4)$, calcium antagonists $(n=1)$, and ACE-inhibitors plus diuretic $(n=1)$ at the time of surgery.

The local research committee of the General Regional Hospital Number 1, Instituto Mexicano del Seguro Social (IMSS), Morelia, Michoacán, México, approved the experimental protocol. All patients gave informed consent to participate in the study.

\section{Samples}

Abdominal subcutaneous adipose tissue samples weighing from 2.5 to $10 \mathrm{~g}$ were obtained by biopsy during elective abdominal surgery, under general anesthesia or epidural blockage, 5 minutes after opening the abdominal wall and before further surgical procedures. The patients had fasted from $10 \mathrm{pm}$ the previous day before undergoing surgery. General anesthesia was induced at about 8 am by a shortacting barbiturate and maintained by sevoflurane plus fentanyl and oxygen (balanced anesthesia) or epidural blockage induced with lidocaine $2 \%$. After removal of adipose tissue, specimens were stored in sterile cold $\left(2^{\circ} \mathrm{C}-4^{\circ} \mathrm{C}\right)$ phosphatebuffered saline (PBS) with the addition of $500 \mathrm{IU} / \mathrm{mL}$ penicillin and $500 \mu \mathrm{g} / \mathrm{mL}$ streptomycin and immediately transferred to the laboratory to be processed within the following 30 minutes.

\section{Materials}

DA, NE, prolactin, and propranolol ( $\beta$-adrenergic receptor antagonist) were purchased from Sigma-Aldrich (St Louis, MO, USA). Metoclopramide (DAergic antagonist) and NPH human insulin were provided by the pharmaceutical companies Hoechst Marion Russell (Mexico City, Mexico) and Eli Lilly (Mexico City, Mexico), respectively. Dulbecco's Modified Eagle's Medium (DMEM), bovine serum albumin (BSA), collagenase type II, PBS, penicillin and streptomycin, and cell-culture reagents were purchased from Life Technologies (Carlsbad, CA, USA). A Titan one-tube reverse-transcription polymerase chain reaction (RT-PCR) kit (Roche Diagnostics, Basel, Switzerland) was used RT and PCR. Oligonucleotides were purchased from Life Technologies.

\section{Cell culture}

The isolation and culture of the adipose tissue cells were performed following the Rodbell procedure, ${ }^{18}$ with minor modifications, as follows. Tissue samples were weighed and minced; tissue fragments were then digested in fresh PBS penicillin/streptomycin buffer in the presence of type II collagenase $(2 \mathrm{mg} / \mathrm{mL}$ buffering tissue $)$ at $37^{\circ} \mathrm{C}$ with gentle shaking at 200 cycles/minute for 45 minutes. The resulting cell suspension was separated from undigested tissue by filtration through a $400-\mu \mathrm{M}$ nylon mesh and washed three times. For each wash, cells were centrifuged at $500 \mathrm{rpm}$ for 1 minute, and the infranatant was discarded each time. The supernatant adipocytes were resuspended in PBS penicillin/streptomycin buffer. The final wash was in DMEM supplemented with $10 \%$ BSA, sodium bicarbonate, HEPES (4-[2-hydroxyethyl]-1piperazineethanesulfonic acid), penicillin/streptomycin (penicillin $500 \mathrm{IU} / \mathrm{mL}$ and streptomycin $500 \mu \mathrm{g} / \mathrm{mL}$ ). It was then incubated for 30 minutes at a constant temperature of $37^{\circ} \mathrm{C}$ and $5 \% \mathrm{CO}_{2}$, before being plated in culture plates in order to continue the incubation for 72 hours, with DMEM replacement at 24-hour intervals. Viability of the adipocytes was microscopically monitored (ID03 phase-contrast microscope; 
Zeiss, Jena, Germany). Then, the DMEM, without BSA, was used for maintenance of cultured adipocytes during the following treatments: DA $(0.001,0.01,0.1$, and $1.0 \mu \mathrm{mol} / \mathrm{L})$; DA $(1.0 \mu \mathrm{mol} / \mathrm{L})$ plus metoclopramide $(1.0 \mu \mathrm{mol} / \mathrm{L})$; NE $(1.0 \mu \mathrm{mol} / \mathrm{l})$; NE $(1.0 \mu \mathrm{mol} / \mathrm{L})$ plus propranolol $(20 \mu \mathrm{g} / \mathrm{mL})$; and insulin $(0.1 \mu \mathrm{mol} / \mathrm{L})$ or prolactin $(1.0 \mu \mathrm{mol} / \mathrm{L})$. All treatments were maintained for 24 hours, with the exception of insulin treatment (which was maintained for 72 hours), in order to evaluate their effects on adipocyte $O B$ gene expression and leptin release. Each experiment was performed six times in different cultured adipocytes obtained by biopsies, ie, in six plates incubated simultaneously, and was repeated in two separate experiments. At the end of the 24- or 72-hour treatment period, culture medium corresponding to adipocytes receiving the different treatments was frozen and stored at $-70^{\circ} \mathrm{C}$ until assay. Cultured adipocytes in the plates under the different treatments were prepared for total ribonucleic acid (RNA) extraction.

\section{Total RNA extraction and reverse- transcription polymerase chain reaction}

Total RNA from cultured cells was prepared with the use of TRIzol ${ }^{\circledR}$ Reagent (Life Technologies) according to the manufacturer's protocol. Agarose gel electrophoresis and ethidium bromide staining assessed the integrity of the adipocyte RNA samples. The RNA samples were then diluted appropriately to equalize concentrations, and stored at $-70^{\circ} \mathrm{C}$ until use. RT and amplification of complementary deoxyribonucleic acid (cDNA) was carried out by PCR. RT-PCR was performed with the Titan one-tube RT-PCR kit. Using avian myeloblastosis virus for first-strand synthesis and the Expand HighFidelity enzyme blend (Roche), which consisted of Taq DNA polymerase and Pwo DNA polymerase for the PCR part, a one-step reaction system was performed. In addition, the system included a single optimized RT-PCR buffer, control RNA from a human cell line (K562), and control primers for human $\beta$-actin messenger RNA (mRNA). Master mix 1 was composed of deoxyribonucleotide triphosphate mix $0.2 \mathrm{nM}$ (each), dithiothreitol solution $5 \mathrm{mM}$, ribonuclease inhibitor $5 \mathrm{U}$, control primer mix $0.4 \mu \mathrm{M}$ (each), downstream leptin primer $0.4 \mu \mathrm{M}$ (each), upstream leptin primer $0.4 \mu \mathrm{M}$, control RNA 10 pg, template RNA $600 \mathrm{ng}$, and sterile water for a volume of $25 \mu \mathrm{L}$. Master mix 2 was composed of $5 \times$ RT-PCR buffer, enzyme mix ( $1 \mu \mathrm{L})$, and sterile water for a volume of $25 \mu \mathrm{L}$. Then, $25 \mu \mathrm{L}$ each of master mixes 1 and 2 was added to a $0.2 \mathrm{~mL}$ thin-walled PCR tube on ice. The sample was mixed and collected at the bottom of the tube, and was briefly centrifuged and overloaded with $30 \mu \mathrm{L}$ mineral oil.
The PCR primers used were: leptin, sense $5^{\prime}$-CAT TGG GGA ACC CTG TGC GGA-3' and antisense 5'-TGG CAG CTC TTA GAG AAG GCC-3'; $\beta$-actin, sense 5'-CCA AGG CCA ACC GCG AGA AGATGA C-3' and antisense 5'-AGG GTA CAT GGT GGT GCC GCC AGA C-3'. PCR products of leptin and $\beta$-actin generated fragments of $260 \mathrm{bp}$ and $587 \mathrm{bp}$, respectively, when they were amplified. The $\beta$-actin was used as the housekeeping gene and amplified with leptin as internal control. Samples were placed in a Delta Cycler System P/W TCX80 (San Diego, CA, USA), equilibrated at $50^{\circ} \mathrm{C}$, and incubated for 30 minutes for the RT. The cDNA synthesis reaction PCR was accomplished in 37 cycles; $1 \times$ denature template at $94^{\circ} \mathrm{C}$ for 1 minute, $10 \times$ denaturation at $94^{\circ} \mathrm{C}$ for 30 seconds, annealing at $60^{\circ} \mathrm{C}$ for 30 seconds, and elongation at $72^{\circ} \mathrm{C}$ for 2 minutes; $25 \times$ denaturation at $94^{\circ} \mathrm{C}$ for 1 minute, annealing at $60^{\circ} \mathrm{C}$ for 30 seconds, and elongation at $72^{\circ} \mathrm{C}$ for 2 minutes; elongation at $72^{\circ} \mathrm{C}(2$ minutes) plus five seconds for each cycle (eg, cycle 11 added 5 seconds, cycle 12 added 10 seconds, cycle 13 added 15 seconds); $1 \mathrm{x}$ of elongation time at $72^{\circ} \mathrm{C}$ lasted 7 minutes. The products of the amplification were resolved by electrophoresis in $2 \%$ agarose gel. The band densities were quantified using the RFLPscan 2.1 software (Scan analytics, Billerica, MA, USA).

\section{Measurement of leptin}

Leptin levels in the culture medium were measured by RIA using a human leptin RIA kit (Linco Research, St Charles, MO, USA). The limit of sensitivity was $0.05 \mathrm{ng} / \mathrm{mL}$. The intra- and interassay coefficients of variation for concentrations of $0.58 \mathrm{ng} / \mathrm{mL}$ and $0.53 \mathrm{ng} / \mathrm{mL}$ were $1.8 \%$ and $4.9 \%$ and $3.6 \%$ and $6.6 \%$, respectively.

\section{Statistical analysis}

Results from six experiments are expressed as means \pm standard error. Statistical tests were performed using the SPSS, version 18 for Windows (IBM, Armonk, NY, USA). The Kolmogorov-Smirnov one-sample test was used to test for normal distribution of data. Student's $t$-test was used for comparisons of the means of the values of the clinic variables and leptin release of the cultured adipocytes from obese hypertensive and nonobese normotensive patients. One-way analysis of variance followed by Tukey's post hoc test was used to compare mean values of leptin release and $O B$ gene expression under different treatments, with $P<0.05$ considered statistically significant. 


\section{Results}

The clinical characteristics of the subjects are shown in Table 1. At baseline, significant differences between the groups were found in body weight, BMI, and systolic, diastolic, and mean blood pressure.

Figure 1 illustrates changes in leptin release elicited by the different treatments on cultured adipocytes. A significant reduction of leptin was observed when adipocytes were under DA, NE, and NE plus propranolol treatments, whereas there was a significant increase of leptin release under prolactin treatment compared to leptin release in untreated adipocytes. The changes observed in values of leptin in culture medium were not significantly different under DA plus metoclopramide, or insulin treatments compared to the control. The data for leptin release in the two groups are depicted in Figure 2. Leptin release from cultured adipocytes from obese hypertensive patients was fivefold higher than cultured adipocytes from the nonobese normotensive patients $(P<0.0001)$ under control conditions. Figure $3 \mathrm{~A}$ shows a significant reduction in leptin release obtained in cultured adipocytes from obese hypertensive patients exposed to $1 \mu \mathrm{mol} / \mathrm{L}$ DA (by $0.450 \pm 0.325 \mathrm{ng} / \mathrm{mL}, P=0.04$ ) and $1.0 \mu \mathrm{mol} / \mathrm{L} \mathrm{NE}$ (by $0.300 \pm 0.226 \mathrm{ng} / \mathrm{mL}, P=0.001)$ and a significant increase with $1.0 \mu \mathrm{mol} / \mathrm{L}$ prolactin (by $0.862 \pm 0.366 \mathrm{ng} / \mathrm{mL}$, $P=0.04$ ), whereas only a significant reduction in leptin release was observed in cultured adipocytes from nonobese normotensive patients exposed to $1.0 \mu \mathrm{mol} / \mathrm{L} \mathrm{DA}$ (by $0.062 \pm 0.016 \mathrm{ng} / \mathrm{mL}, P=0.008$ ) and $1.0 \mu \mathrm{mol} / \mathrm{L} \mathrm{NE}$ (by $0.054 \pm 0.016 \mathrm{ng} / \mathrm{mL}, P=0.005$ ). These results are

Table I Clinical characteristics of obese hypertensive patients and nonobese normotensive patients who provided adipose tissue samples for cultured adipocytes

\begin{tabular}{|c|c|c|c|}
\hline & $\begin{array}{l}\text { Obese and } \\
\text { hypertensive } \\
\text { patients* } \\
n=16\end{array}$ & $\begin{array}{l}\text { Nonobese and } \\
\text { normotensive } \\
\text { patients* } \\
n=5\end{array}$ & $P$ \\
\hline Age (years) & $51 \pm 8$ & $48 \pm 4$ & 0.424 \\
\hline Sex (male/female) & $6 / 10$ & $2 / 3$ & \\
\hline Weight (kg) & $83 \pm 8$ & $63 \pm 6$ & 0.005 \\
\hline Height (m) & $1.59 \pm 0.5$ & $1.59 \pm 0.4$ & 0.798 \\
\hline BMI $\left(\mathrm{kg} / \mathrm{m}^{2}\right)$ & $32.9 \pm 2.0$ & $24.9 \pm 1.1$ & $<0.000$ I \\
\hline $\begin{array}{l}\text { Systolic blood } \\
\text { pressure }(\mathrm{mmHg})\end{array}$ & $149 \pm 9$ & $120 \pm 7$ & $<0.0001$ \\
\hline $\begin{array}{l}\text { Diastolic blood } \\
\text { pressure }(\mathrm{mmHg})\end{array}$ & $93 \pm 5$ & $78 \pm 4$ & $<0.0001$ \\
\hline $\operatorname{MBP}(\mathrm{mmHg})^{* *}$ & $111 \pm 5$ & $92 \pm 5$ & $<0.0001$ \\
\hline
\end{tabular}

Notes: *Mean \pm standard error; $* * M B P=$ diastolic pressure $+1 / 3$ of difference (systolic/diastolic pressure).

Abbreviations: BMI, body mass index; MBP, mean blood pressure. shown in Figure 3B. Insulin $(0.1 \mu \mathrm{mol} / \mathrm{L})$ and prolactin $(1.0 \mu \mathrm{mol} / \mathrm{L})$ treatments were ineffective.

Figure 4 illustrates percentage changes in the content of $O B$ gene mRNA expression of cultured adipocytes under the different treatments in comparison to leptin mRNA band density in cultured adipocytes not exposed to any treatment $(100 \%)$. A significant reduction of $O B$ gene mRNA expression was observed under $1.0 \mu \mathrm{mol} / \mathrm{L}$ of DA (to $54 \% \pm 4 \%, P=0.02$ ), while the effect under DA plus metoclopramide treatment was not statistically significant. In addition, NE elicited a significant reduction of $O B$ gene mRNA expression (to $68 \% \pm 6 \%, P=0.001$ ), which was not completely reversed by propranolol. Insulin treatment did not induce significant modifications in $O B$ gene mRNA expression of cultured adipocytes. Nevertheless, prolactin treatment elicited a significant increase of $O B$ gene mRNA expression (to $48 \% \pm 18 \%, P=0.04$ ).

In addition, when cultured adipocytes of obese hypertensive patients were exposed to different concentrations of DA, a dose-dependent reduction of $O B$ gene mRNA expression was observed, with significant reductions attained using DA $0.1 \mu \mathrm{mol} / \mathrm{L}$ and DA $1.0 \mu \mathrm{mol} / \mathrm{L}(52 \% \pm 2.4 \%$, $P<0.05$, and $63 \% \pm 1.2 \%, P=0.01$, respectively), and leptin release (from $0.71 \pm 0.329 \mathrm{ng} / \mathrm{mL}$ to $0.47 \pm 0.116 \mathrm{ng} / \mathrm{mL}$, $P=0.01$, and from $0.71 \pm 0.329 \mathrm{ng} / \mathrm{mL}$ to $0.32 \pm 0.08 \mathrm{ng} / \mathrm{mL}$, $P<0.0001$, respectively) (Figure 5A-C).

\section{Discussion}

Our data confirm that leptin release was fivefold higher in cultured adipocytes obtained from obese hypertensive patients compared to nonobese normotensive patients. Moreover, this study demonstrates that whereas DA and NE exert inhibitory effects on leptin release and $O B$ gene expression, prolactin increases leptin release and $O B$ gene expression in cultured adipocytes from both obese hypertensive patients and nonobese normotensive patients. Thus, our results suggest that DAergic deficiency may contribute at least in part to metabolic disorders linked to hyperleptinemia in obese hypertensive patients.

The finding that NE reduced $O B$ gene expression is in agreement with results from previous studies in cultured 3T3-LI adipocytes ${ }^{16}$ and in cultured adipocytes from obese patients. ${ }^{19}$ Moreover, NE addition to the culture resulted in a significant reduction of leptin release from cultured adipocytes from obese hypertensive patients, which was partially prevented by propranolol administration, in agreement with a previous report. ${ }^{16}$ The partial reduction of the NE effects induced by propranolol could be due to the participation of 


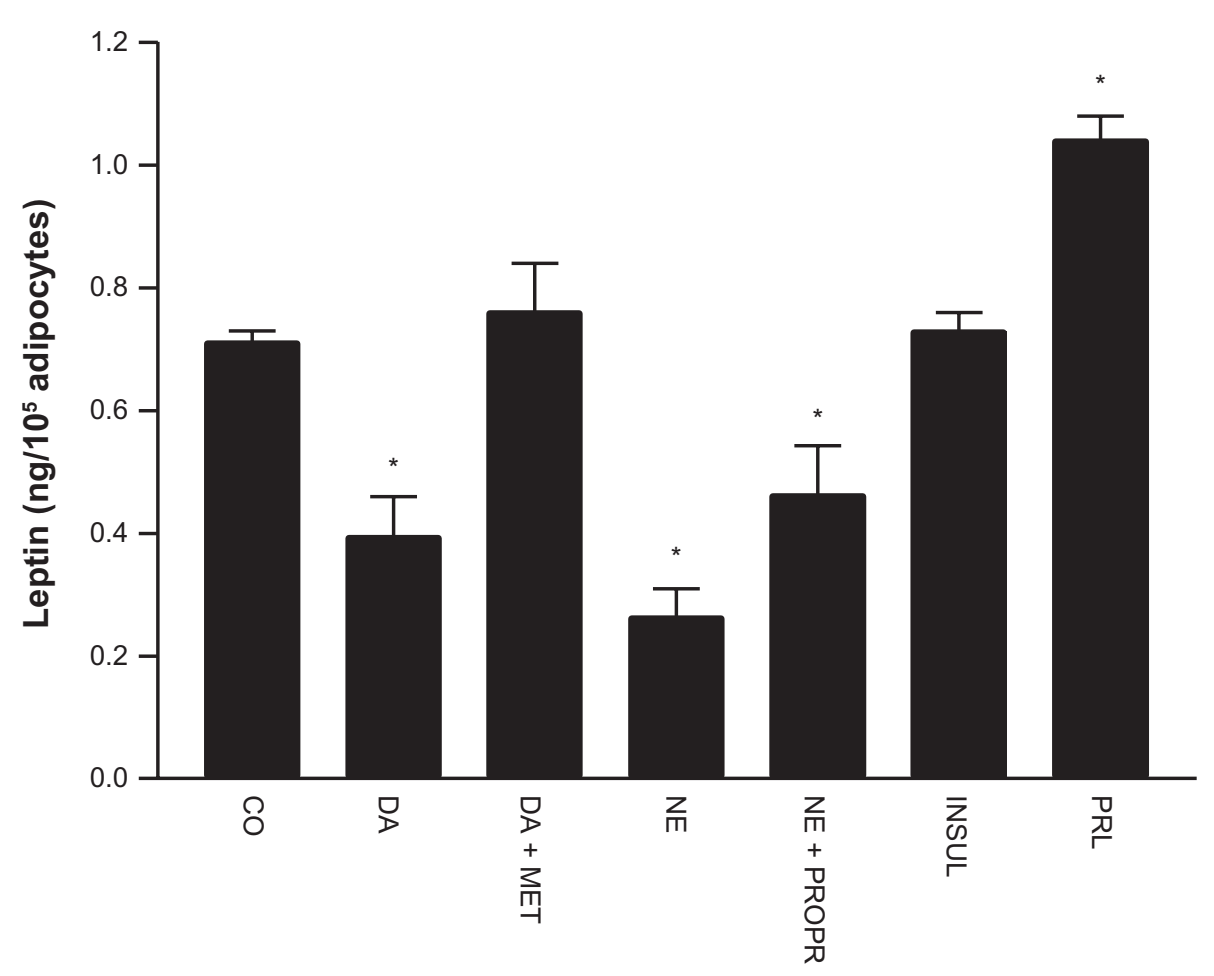

Figure I Effects of different treatments on leptin release in cultured human adipocytes from obese hypertensive patients. Values (means \pm standard error) are expressed as leptin concentrations in the culture medium. Control (CO), regular medium alone; dopamine (DA; I.0 $\mu \mathrm{mol} / \mathrm{L})$; DA (I.0 $\mu \mathrm{mol} / \mathrm{L})$ plus metoclopramide (MET; I.0 $\mu \mathrm{mol} / \mathrm{L})$;

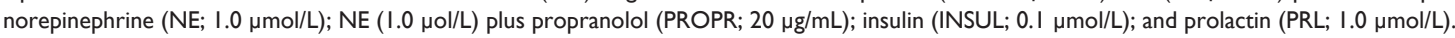

Notes: $* \mathrm{p}<0.05$ versus control (as the reference group). One-way analysis of variance and Tukey's post hoc test, $\mathrm{n}=7$ per group, performed in duplicate.

the $\beta_{3}$-adrenergic receptor, because propranolol is known to be an antagonist for the $\beta_{1}$ - and $\beta_{2}$-adrenergic receptors. ${ }^{20}$ Thus, our results support the hypothesis of noradrenergic involvement in cellular mechanisms resulting in leptin release and $O B$ gene expression, suggesting that leptin release is modified in parallel with $O B$ gene expression.
The chief finding of the present study was the DAergic effect on leptin release and $O B$ gene expression in cultured adipocytes, similar to that induced by NE. In fact, DA elicited a dose-related reduction of both leptin release and $O B$ gene expression in cultured adipocytes, possibly mediated by $\mathrm{DA}_{2}$ receptors, since metoclopramide administration resulted in

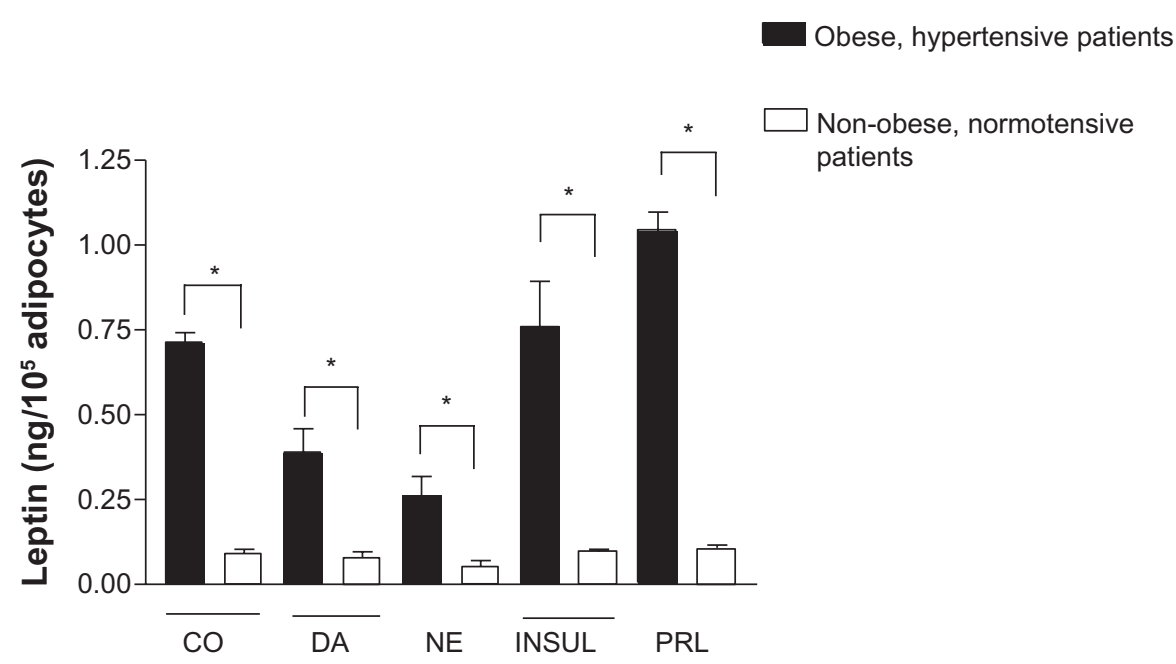

Figure 2 Values (means \pm standard error) of leptin release from cultured adipocytes from nonobese normotensive patients, and from cultured adipocytes from obese hypertensive patients. Note the significantly higher values of leptin release from adipocytes from obese hypertensive patients in both control and treatment conditions. Notes: $* P<0.05$, Student's test; control (CO), regular medium alone; dopamine (DA; I.0 $\mu \mathrm{mol} / \mathrm{L}$ ); norepinephrine (NE; I.0 $\mu \mathrm{mol} / \mathrm{L})$; insulin (INSUL; 0.1 mol/L); and prolactin (PRL; $1.0 \mu \mathrm{mol} / \mathrm{L})$. 
A

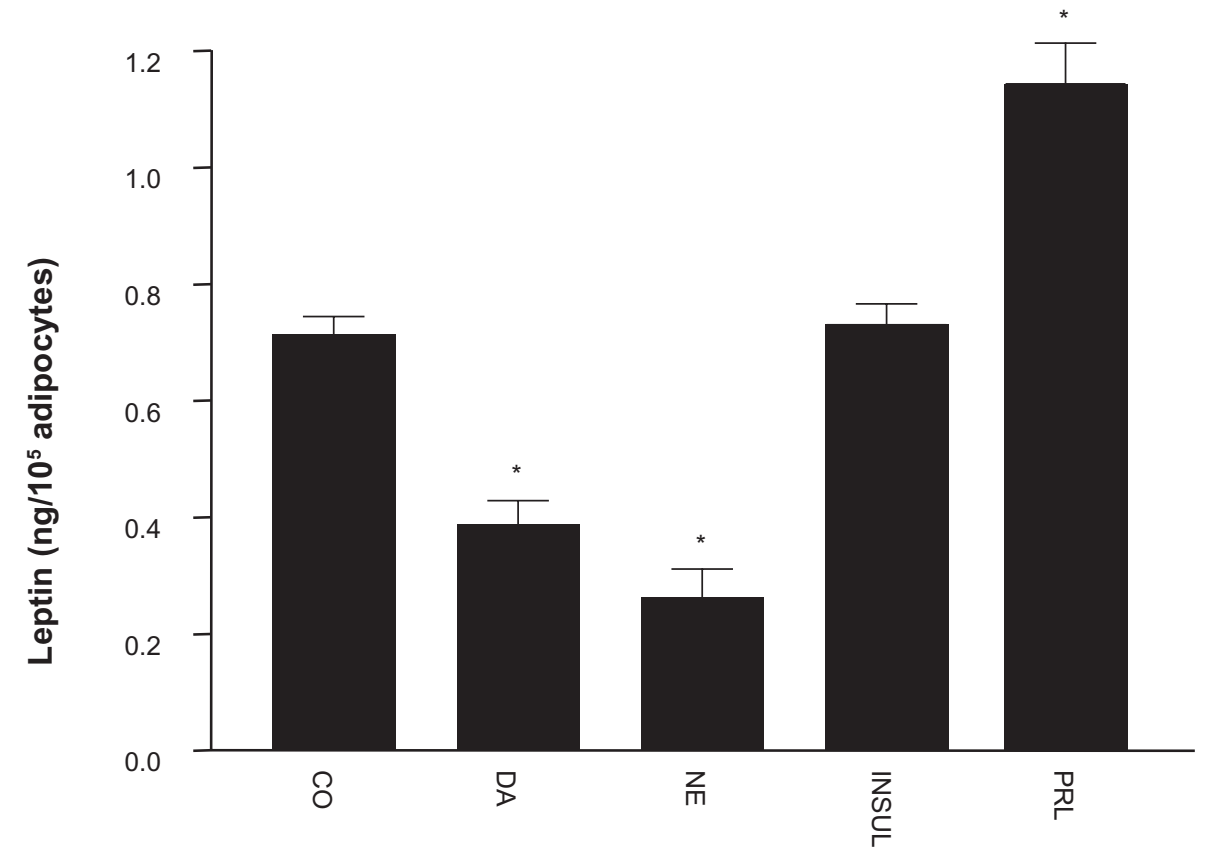

B

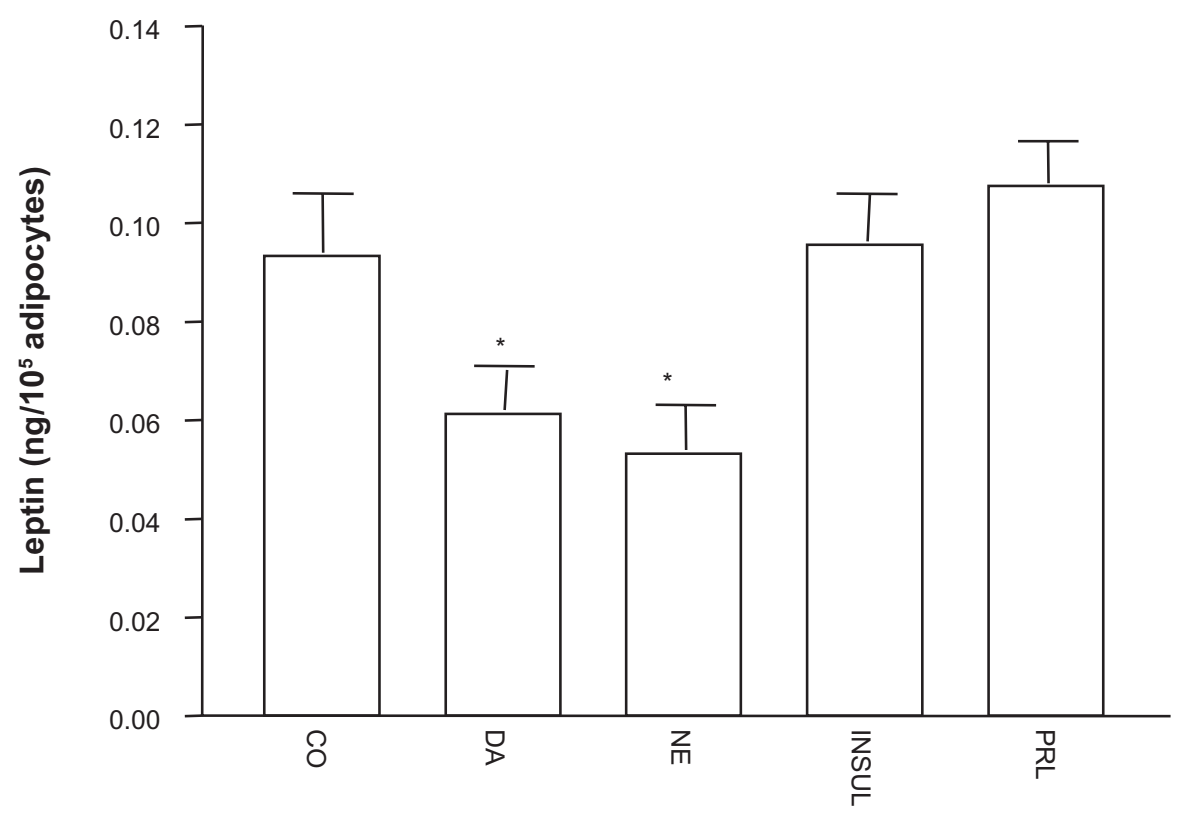

Figure 3 (A and B) Values (means \pm standard error) of leptin release from cultured adipocytes under DA (I.0 $\mu \mathrm{mol} / \mathrm{L}), \mathrm{NE}(\mathrm{I} .0 \mu \mathrm{mol} / \mathrm{L})$, INSUL (0.I $\mu \mathrm{mol} / \mathrm{L})$, and PRL $(1.0 \mu \mathrm{mol} / \mathrm{L})$ treatments. Leptin release from cultured adipocytes from obese hypertensive patients $(\mathbf{A})$, and from nonobese normotensive patients $(\mathbf{B})$. Note the different values on ordinates.

Notes: $* P<0.05$, one-way analysis of variance and Tukey's post hoc test, $\mathrm{n}=5$ per group, performed in duplicate.

Abbreviations: CO, control; DA, dopamine; NE, norepinephrine; INSUL, insulin; PRL, prolactin.

abolishment of the DA effect. Involvement of $G\left(G_{i} / G_{0}\right)$ proteins, adenylate cyclase, and phospholipase $\mathrm{C}$ has been proposed, accounting for $\mathrm{DA}_{2}$-mediated DA effects. ${ }^{21}$ Since DA and NE have negative effects on leptin release and $O B$ gene expression, it appears that increments in body fat and as a consequence leptin overproduction precede sympathetic activity. This finding suggests that interactions between sympathetic overactivity and hyperleptinemia in obese hypertensive patients are dependent primarily on increments in body fat. 
A

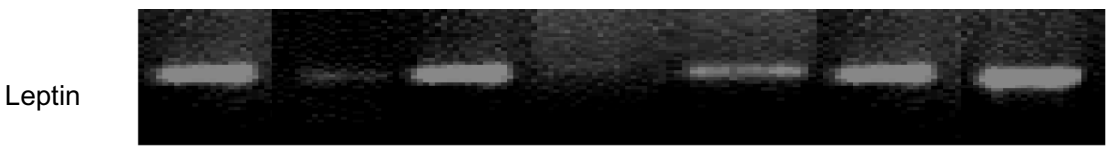

$\beta$-actin

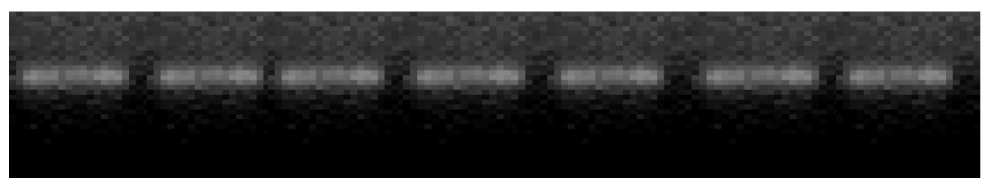

B

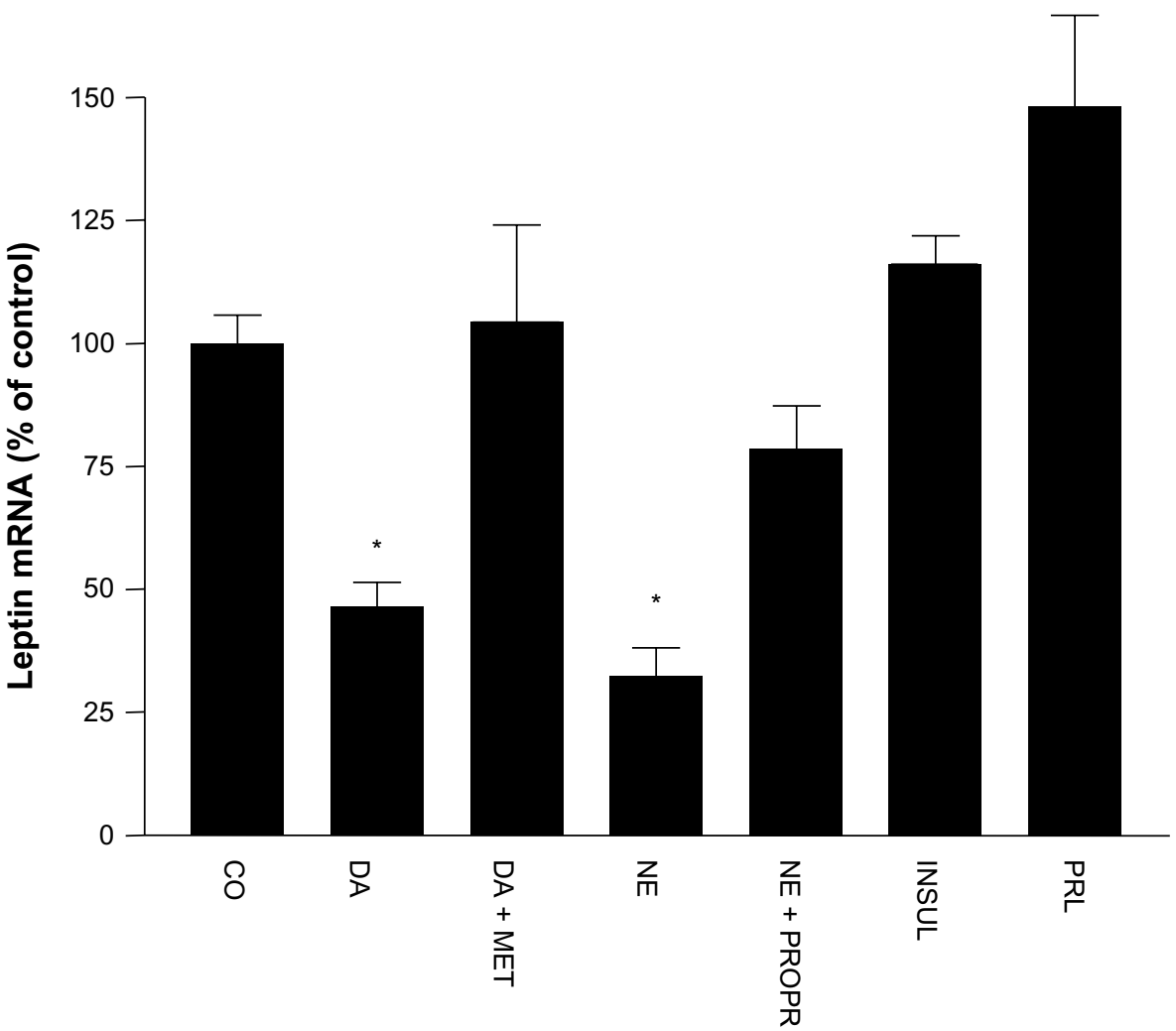

Figure 4 ( $\mathbf{A}$ and $\mathbf{B})$ Effects of the different treatments on leptin messenger ribonucleic acid (mRNA) resulting from $O B$ leptin gene expression in culture from obese and hypertensive patients. (A) Representative bands of $O B$ gene mRNA, using $\beta$-actin as internal control. (B) Percentage values (means \pm standard error) of $O B$ gene mRNA in reference to control conditions.

Notes: $* P<0.05$, one-way analysis of variance and Tukey's post hoc test, $n=7$ per group, performed in duplicate; control (CO), regular medium alone; dopamine (DA;

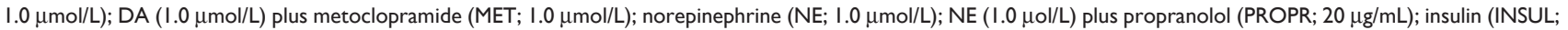
$0.1 \mu \mathrm{mol} / \mathrm{L})$; and prolactin (PRL; I.0 $\mu \mathrm{mol} / \mathrm{L})$.

Although we did not test the effect of leptin on DA or NE production, circulating leptin has been suggested to contribute to increased blood pressure in obesity by activation of the sympathetic nervous system..$^{22}$ As leptin-binding sites have been found in regions of the brain that are important in cardiovascular control, ${ }^{23}$ and chronic leptin infusion exerts longterm effects on cardiovascular and renal function, ${ }^{12,24}$ it seems conceivable that leptin could modify cardiovascular function through central nervous system effects. Evidence suggests that endogenous DA modulates NE synthesis and secretion in the noradrenergic neurons ${ }^{25}$ and - at least in part - leptin release and $O B$ gene expression in adipose tissue. As DAergic activity is reduced in subjects with hypertension and obesity, ${ }^{3}$ this could explain in part that obesity, ${ }^{26}$ sympathetic hyperactivity, ${ }^{27}$ and hyperleptinemia ${ }^{28}$ are associated with hypertension. We did not find effects of insulin on leptin release and $O B$ gene expression in cultured adipocytes. These results are in accordance with previous reports published on primary cultures of adipocytes. ${ }^{28}$ However, other studies have demonstrated that insulin causes an increase in leptin release 


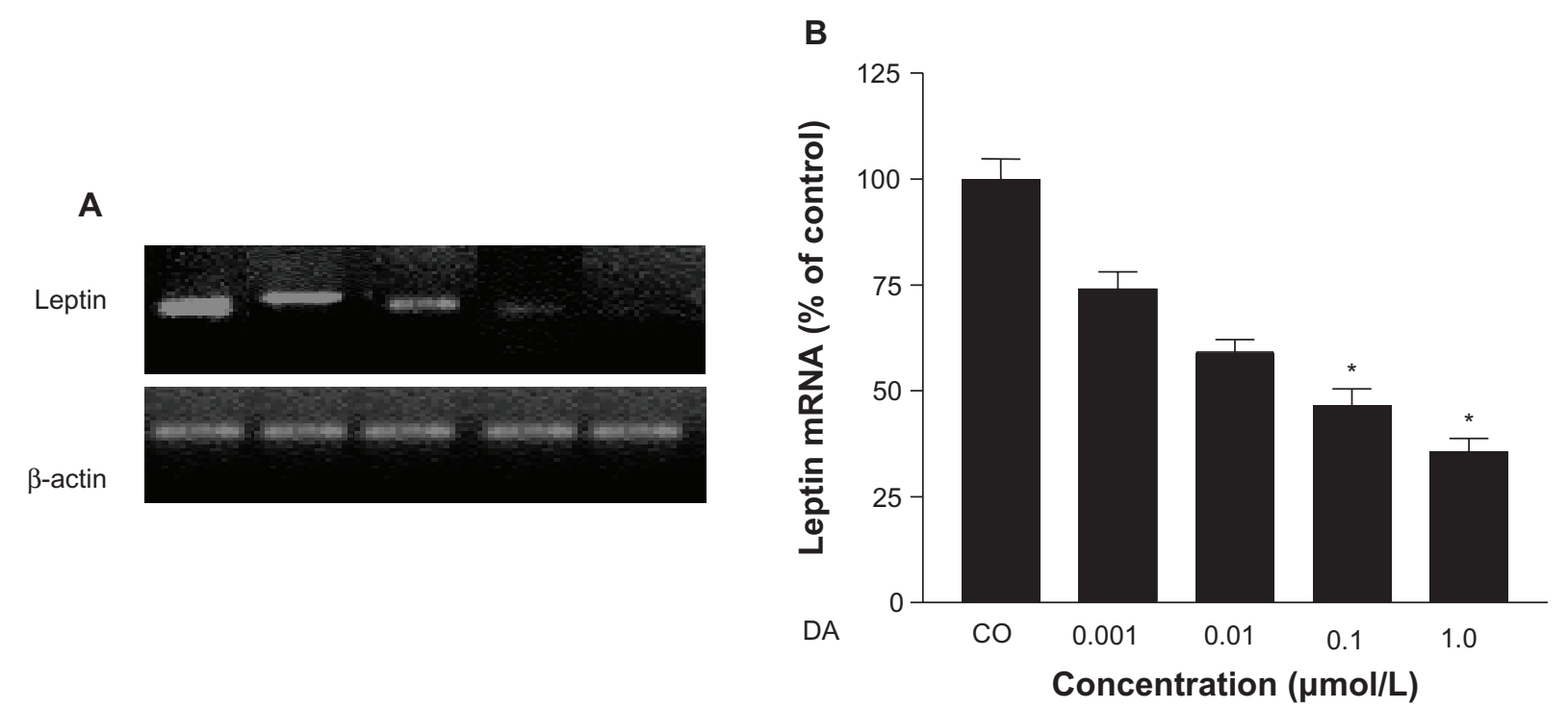

C

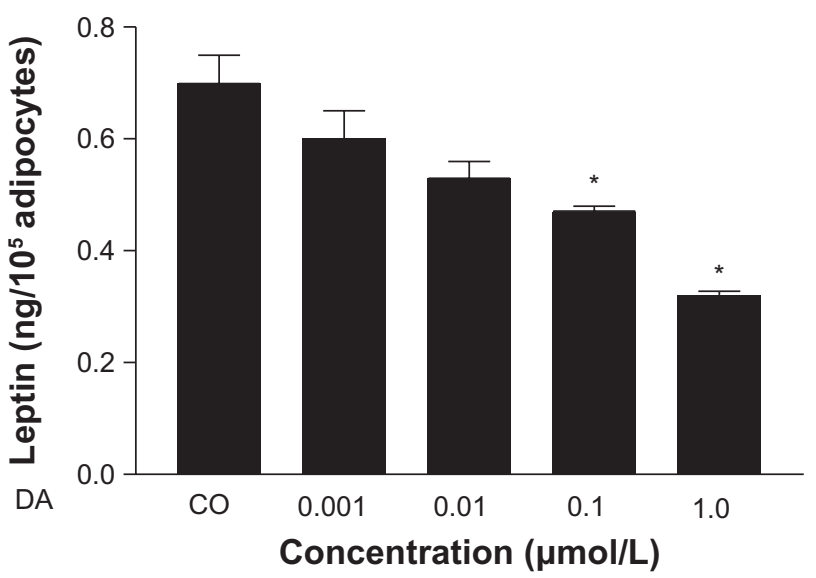

Figure 5 (A-C) Dose-dependent reduction of $O B$ gene messenger ribonucleic acid (mRNA) and leptin release induced by dopamine (DA) in cultured human adipocytes of obese, hypertensive patients. (A) Representative bands of $O B$ gene mRNA. (B) Percentage values (means \pm standard error) of leptin mRNA in reference to control conditions. (C) Leptin release under different concentrations of DA in reference to control.

Notes: $* P<0.05$, one-way analysis of variance and Tukey's post hoc test, $n=5$ per group, performed in duplicate.

and $O B$ gene expression both in vivo ${ }^{29}$ and in vitro. ${ }^{13}$ There are at least three possible explanations for this discrepancy. One is the type of insulin used. In this study, NPH human insulin was used with pharmacokinetic properties of onset of action of 1-2 hours, maximum action of 6-12 hours, and duration up to 18-24 hours. However, we measured leptin at 24,48 , and 72 hours, so the effect might have been able to be observed before 24 hours. Another explanation is that cultured cells require a longer stimulation period; however, in the present study, this is not a probable explanation, since we kept the cells in culture for 72 hours. A third explanation may be that insulin causes an increase in leptin release and $O B$ gene expression only in vivo.

Although prolactin is a peptide hormone produced mainly in the anterior pituitary, it is also synthesized in extrapituitary sites ${ }^{30}$ including adipocytes. Hyperprolactinemia, suggesting decrease of DAergic activity, is found in patients with hypertension, ${ }^{31}$ obesity, ${ }^{32}$ and chronic kidney disease, ${ }^{33}$ ie, conditions associated with hyperleptinemia. We confirm that prolactin increases leptin release and $O B$ gene expression in adipocytes cultured from subcutaneous fat of humans. However, results of recent studies suggest that the response is reciprocal in both directions, since on the one hand it has been found that leptin regulates DA in response to sustained stress and eating behavior in humans, implicating involvement of DAergic pathways in this response, ${ }^{34,35}$ and on the other hand a study in an experimental model showed that prolactin inhibits lipolysis and leptin release. ${ }^{36}$ These discrepancies may be due to several factors, such as doses of DA and prolactin, experimental design, species, or sex. 


\section{Summary and conclusion}

In the current study, DA and NE were found to decrease leptin release and $O B$ gene expression in cultured adipocytes from subcutaneous fat tissue of obese hypertensive patients and nonobese normotensive patients, while there was an opposite effect of prolactin in cultured adipocytes from obese hypertensive patients. The clinical significance of these findings remains to be clarified in future studies; however, our observations support links between hyperprolactinemia, fat mass, hyperleptinemia, and hypertension. While recognizing that the investigated interactions are much more complex in vivo in the setting of numerous interrelated pathways interacting simultaneously, and likely to result in a variable response, the in vitro study of the dose-dependent response of these pathways under controlled situations, such as in the current study, could be a useful step to further our understanding of the much more complex mechanism in vivo in a sequential manner.

\section{Acknowledgments}

This investigation was supported by the Instituto Mexicano del Seguro Social, and by CONACYT/FOSIMORELOS grant 9903-02-028. We thank the patients who donated adipose tissue for these studies. We also gratefully acknowledge the support of staff of surgery and anesthesia of the General Regional Hospital Number 1, IMSS, Morelia, Michoacán, Mexico. Baxter Novum is the result of a grant to the Karolinska Institutet from Baxter Healthcare Corporation. Baxter Healthcare Corporation employs Bengt Lindholm.

\section{Disclosure}

The authors report no conflicts of interest in this work.

\section{References}

1. Ferranini E, Cushman WC. Diabetes and hypertension: the bad companions. Lancet. 2012;380(9841):601-610.

2. Landsberg L. Pathophysiology of obesity-related hypertension: role of insulin and the sympathetic nervous system. J Cardiovasc Pharmacol. 1994;23 Suppl 1:S1-S8.

3. Kuchel OG, Kuchel GA. Peripheral dopamine in pathophysiology of hypertension. Interaction with aging and lifestyle. Hypertension. 1991;18(6):709-721.

4. Kolloch R, Kobayashi K, DeQuattro V. Dopaminergic control of sympathetic tone and blood pressure: evidence in primary hypertension. Hypertension. 1980;2(4):390-394.

5. Ziegler MG, Lake CR, Williams AC, Teychenne PF, Shoulson I, Steinsland O. Bromocriptine inhibits norepinephrine release. Clin Pharmacol Ther. 1979;25(2):137-142.

6. Kok P, Roelfsema F, Frölich M, van Pelt J, Meinders AE, Pijl H. Activation of dopamine D2 receptors lowers circadian leptin concentrations in obese women. J Clin Endocrinol Metab. 2006;91(8):3236-3240.

7. Pijl H, Ohashi S, Matsuda M, et al. Bromocriptine: a novel approach to the treatment of type 2 diabetes. Diabetes Care. 2000;23(8):1154-1161.
8. Zhang Y, Proenca R, Maffei M, Barone M, Leopold L, Friedman JM. Positional cloning of the mouse obese gene and its human homologue. Nature. 1994;372(6505):425-432.

9. Pelleymounter MA, Cullen MJ, Baker MB, et al. Effects of the obese gene product on body weight regulation in ob/ob mice. Science. 1995;269(5223):540-543.

10. Considine RV, Sinha MK, Heiman ML, et al. Serum immunoreactiveleptin concentrations in normal-weight and obese humans. $N$ Engl J Med. 1996;334(5):292-295.

11. Alvarez-Aguilar C, Mondragón-Jiménez LI, Ramírez-Enríquez J, Gómez-García A, Paniagua-Sierra R, Amato D. Hiperleptinemia como factor de riesgo en hipertensión arterial asociada a obesidad [Hyperleptinemia as a risk factor in obesity-related hypertension]. Med Clin (Barc). 2004;123(20):766-769. Spanish.

12. Shek EW, Brands MW, Hall JE. Chronic leptin infusion increases arterial pressure. Hypertension. 1998;31(1):409-414.

13. Bradley RL, Cheatham B. Regulates of ob gene expression and leptin secretion by insulin and dexamethasone in rat adipocytes. Diabetes. 1999;48(2):272-278.

14. Masuzaki H, Ogawa Y, Hosoda K, et al. Glucocorticoid regulation of leptin synthesis and secretion in humans: elevated plasma leptin levels in Cushing's syndrome. J Clin Endocrinol Metab. 1997;82(8): 2542-2547.

15. Gualillo O, Lago F, García M, et al. Prolactin stimulates leptin secretion by rat white adipose tissue. Endocrinology. 1999;140(11):5149-5153.

16. Kosaki A, Yamada K, Kuzuya H. Reduced expression of the leptin gene $(\mathrm{ob})$ by catecholamine through a $\mathrm{G}(\mathrm{S})$ protein-coupled pathway in 3T3-L1 adipocytes. Diabetes. 1996;45(12):1744-1749.

17. Galic S, Oakhill JS, Steinberg GR. Adipose tissue as an endocrine organ. Mol Cell Endocrinol. 2010;316(2):129-139.

18. Rodbell M. Metabolism of isolated fat cells. I. Effects of hormones on glucose metabolism and lipolysis. J Biol Chem. 1964;239(2):375-380.

19. Carulli L, Ferrari S, Bertolini M, Tagliafico E, Del Rio G. Regulation of ob gene expression: evidence for epinephrineinduced suppression in human obesity. J Clin Endocrinol Metab. 1999;84(9):3309-3312.

20. Mantzoros CS, Qu D, Frederich RC, et al. Activation of beta(3) adrenergic receptors suppresses leptin expression and mediates a leptin-independent inhibition of food intake in mice. Diabetes. 1996; 45(7):909-914.

21. Hussain T, Lokhandwala MF. Renal dopamine receptor function in hypertension. Hypertension. 1998;32(2):187-197.

22. Haynes WG, Morgan DA, Walsh SA, Mark AL, Sivitz WI. Receptormediated regional sympathetic nerve activation by leptin. J Clin Invest. 1997;100(2):270-278.

23. Tartaglia LA, Dembski M, Weng X, et al. Identification and expression cloning of a leptin receptor, OB-R. Cell. 1995;83(7):1263-1271.

24. Haynes WG, Sivitz WI, Morgan DA, Walsh SA, Mark AL. Sympathetic and cardiorenal actions of leptin. Hypertension. 1997;30(3):619-623.

25. Mannelli M, Ianni L, Lazzeri C, et al. In vivo evidence that endogenous dopamine modulates sympathetic activity in man. Hypertension. 1999;34(3):398-402.

26. Hall JE, Brands MW, Dixon WN, Smith MJ. Obesity-induced hypertension. Renal function and systemic hemodynamics. Hypertension. 1993;22(3):292-299.

27. Esler M. Sympathetic nervous system: contribution to human hypertension and related cardiovascular diseases. J Cardiovasc Pharmacol. 1995;26 Suppl 2:S24-S28.

28. MacDougald OA, Hwang CS, Fan H, Lane MD. Regulated expression of the obese gene product (leptin) in white adipose tissue and 3T3-L1 adipocytes. Proc Natl Acad Sci U S A. 1995;92(20):9034-9037.

29. Boden G, Chen X, Kolaczynski JW, Polansky M. Effects of prolonged hyperinsulinemia on serum leptin in normal human subjects. J Clin Invest. 1997;100(5):1107-1113.

30. Ben-Jonathan N, Mershon JL, Allen DL, Steinmetz RW. Extrapituitary prolactin: distribution, regulation, functions, and clinical aspects. Endocr Rev. 1996;17(6):639-669. 
31. Stumpe KO, Kolloch R, Higuchi M, Krück F, Vetter H. Hyperprolactinaemia and antihypertensive effect of bromocriptine in essential hypertension. Identification of abnormal central dopamine control. Lancet. 1977;310(8031):211-214.

32. Ferreira MF, Sobrinho LG, Santos MA, Sousa MF, Uvnäs-Moberg K. Rapid weight gain, at least in some women, is an expression of a neuroendocrine state characterized by reduced hypothalamic dopaminergic tone. Psychoneuroendocrinology. 1998;23(8):1005-1013.

33. Hov SH, Grossman S, Molitch ME. Hyperprolactinemia in patients with renal insufficiency and chronic renal failure requiring hemodialysis or chronic ambulatory peritoneal dialysis. Am J Kidney Dis. 1985;6(4): 245-249.
34. Burghardt PR, Love TM, Stohler CS, et al. Leptin regulates dopamine responses to sustained stress in humans. J Neurosci. 2012;32(44): 15369-15376.

35. Zessen R, Plasse G, Adan RA. Contribution of the mesolimbic dopamine system in mediating the effects of leptin and ghrelin on feeding. Proc Nutr Soc. 2012;71(4):435-445.

36. Brandebourg TD, Bown JL, Jonathan NB. Prolactin upregulates its receptors and inhibits lipolysis and leptin release in male rat adipose tissue. Biochem Biophys Res Commun. 2007;357(2):408-413.

\section{Publish your work in this journal}

The International Journal of Nephrology and Renovascular Disease is an international, peer-reviewed open-access journal focusing on the pathophysiology of the kidney and vascular supply. Epidemiology, screening, diagnosis, and treatment interventions are covered as well as basic science, biochemical and immunological studies. The journal welcomes original research, clinical studies, reviews \& evaluations, expert opinion and commentary, case reports and extended reports. The manuscript management system is completely online and includes a very quick and fair peerreview system, which is all easy to use. Visit http://www.dovepress.com/ testimonials.php to read real quotes from published authors.

Submit your manuscript here: http://www.dovepress.com/international-journal-of-nephrology-and-renovascular-disease-journal 